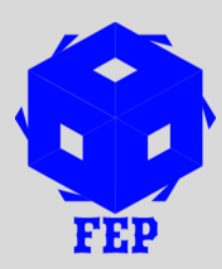

\title{
DEMOCRATIZATION PROCESS AND THE UNFOLDING HISTORICAL DIALETICS OF WOMEN POLITICAL PARTICIPATION IN SUB-SAHARAN AFRICA
}

\author{
${ }^{1}$ Musa Kabir Umar, ${ }^{2}$ Mubarak Ahmed Mashi \\ ${ }^{1 \& 2}$ Department of Political Science, Umaru Musa Yar'adua University Katsina, Katsina State- \\ Nigeria
}

*Corresponding: Musa Kabir Umar
${ }^{1}$ Corresponding Email: kabirbumarmusa@ gmail.com/ kabir.bumar@ umyu.edu.ng

Article Received: 01-05-19 Accepted: 15-07-19 Published: 05-08-19

Licensing Details: Author retains the right of this article. The article is distributed under the terms of the Creative Commons Attribution-NonCommercial 4.0 License

(http://www.creativecommons.org/licences/by-nc/4.0/) which permits non-commercial use, reproduction and distribution of the work without further permission provided the original work is attributed as specified on the Journal open access page.

\begin{abstract}
The main thrust of this paper is centered around examining the historical challenges confronting women political participation in the democratization process of the Sub-Saharan African countries. In the past, indeed, women were never equal to men in the political sphere, because in the precolonial Africa, they were being allowed by men to ruled kingdoms, established cities, launched military conquests, and formed states. However, they unfortunately lost out in such arrangements and the social status with the coming and spread of Islam and Christianity and later colonization. Although women are key actors in the democratization process world over, they have now been politically, socially and economically marginalized especially in the Sub-Saharan African region. Marginalization has been a great challenge to the women of the region due to some socio-religious beliefs that came to the fore particularly with the emergence of Islam and Christianity. Likewise, in the contemporary African politics women are relegated to the background, hence sidelined, without tolerable and equal participation in the governance of their own social formations. The paper, therefore, adopts historical and descriptive approaches to argue that despite the increasing number of women in politics, the political landscape is still largely occupied by men. This is seen in the challenges facing the active political participation of women in the
\end{abstract}


process such as cultural factors, lack of adequate representation and consultation in the political parties' decision-making processes, gender discrimination, lack of fund and so on which the paper revealed. The paper concludes that the involvement of West African women in the democratization process would provide a new track in the developmental agendas of the entire region. And, a specific step to promote gender equality which would advance the status of women and young girls in the process of democratization in Sub-Saharan Africa is greatly needed.

Keywords: Democracy, Democratization Process, Marginalization, Political Participation, Women

\section{INTRODUCTION}

The significance of women's active political participation in the context of democratization process cannot be over-emphasized. Women's political participation naturally guarantees legitimacy, transparency, responsiveness, and accountability of the political system at all governmental levels in the general collective interests (Daniel, 2012; Shimelis, 2014; USAID, 2016; Emeka Eugene Dim and Joseph, 2019). Even though women in precolonial Africa ruled kingdoms, established cities, launched military conquests, and formed states, yet, they were never equal to men in the political sphere (Tripp, 2017). Indeed, with the spread of Islam and Christianity and later colonization; women lost out in such arrangements. When colonial rule became consolidated, western gender philosophy and practices which encourage male supremacy and female dependency have been applied on Africa. Thus, since independence, Africa's male leaders have continued to strengthen the male-controlled structures they inherited from their colonial rulers. This colonial orientation made the support of western international investors and donors' development most often goes to men. Historical facts have recorded that despite women domination by the men; they remain key actors in the democratization process world over (Fallon, Swiss, \& Viterna, 2012). Undisputedly, numerous literatures indicated that there were several great women in the Sub-Saharan African region who contributed immensely to the development of their societies since before independence. For instance, the 'Dahomey Amazons' in the present-day Benin Republic were known for being brave in contributing to the defunct Benin kingdoms military power. Other African women who enormously contributed in the advancement of Africa both socially and politically include Gisele Rabesahala of Madagaska; Wangari Mathai of Kenya; Queen Nzinga Mbandi of Angola; Cesaria Evora of Cape Verde; Miriam Makeba of South Africa; Yaa Asantewa of Ghana and the most recent Ellen Sirleaf Johnson former President of Liberia. And, there were women like Iyalode Efunsetan Aniwura of Ibadan, Queen Amina of Zaria, Emotan of Benin, Princess Inikpi of Igala and Princess Moremi of Ife all in Nigerian pre-colonial days. Still, in the post-colonial days, women such as Mrs Margaret Ekpo of Calabar, Madam Tinubu of Lagos and Egbaland; Mrs Funmilayo Ransome-Kuti of the Abeokuta Women Union (AWU) and Hajiya Sawaba Gambo of Northern Element Progressive Union (NEPU) have also left an indelible mark in the movement of democratization and self-government (Olusegun, 2015). Accordingly, their actions were able to save their societies from insecurity, famine, inequality and the vagaries of war. 
Nevertheless, in the contemporary African politics women are relegated to the background, hence, sidelined without tolerable and equal participation in the governance of their own social formations. Poor participation of women has been a serious concern not only in the Sub-Saharan Africa, but also at the global level. Certainly, public sphere is seen as a malecontrolled domain where they hold leadership positions and dominate decision-making processes while side-lining the womenfolk (Heeman, 2013). The issue of gender discrimination became a thing of concern in the contemporary discourse of African politics due to their perceived harm and exclusion. Participation of women in African politics has been unequal, discriminative and full of alienation to the highest order despite the myriad contribution they can positively offer. Really, in so many Sub-Saharan African developing democracies women outweigh their men counterparts; even in terms of voting which is the key ingredient of the democratization process itself. It is argued that in the African ancient tradition women were mere exhibitions of their husband's wealth, as appendages, thus leading to systematic marginalization (Olusegun, 2015). But the classic problem here is that ethno-religious tendencies are said to be the likely obstacles which energized the male politicians to hijack the political plane. Sadly, despite the multitude's problems being experienced by women, there is limited concentration of studies in this regard. Growing body of evidence showing the need for an increase in women's involvement in politics, women continue to wait behind men regarding political representation in both developed and developing countries alike, although this situation varies from one context to another (Inter Parliament Union, 2017). In fact, considerable literature has studied gender variances in political involvement of women in Western developed democracies, but little is known about such gaps in the Sub-Saharan African countries (Coffe \& Catherine, 2011). It is in view of these problematic issues revolving around African women participation in politics and its dearth of literature that this paper aimed at exploring the historical dialectics of the Sub-Saharan African women in the democratization process.

Thus, this paper is sub-divided into six parts with the objective of historically analyzing women participation in the democratization process of West African sub-region and their current challenges. Directly after the introduction, the paper examined how the laws and international community positioned women in the decision-making processes with emphasis on Sub-Saharan African region. It is followed by the overview of the democratization process in Sub-Saharan Africa and the Socio-economic and religious challenges facing women participation in the democratization process. In the fourth segment of the paper, it discussed the pattern of democratic participation of African women. This involves how they organize themselves and what provokes them to participate in the democratization process and vice versa. It illustrates the nature and character of how they perceived the marginalization and its resultant effects on the development of democracy in the region. The fifth section of the paper suggests the possible ways to deal with the challenges confronting the Sub-Saharan African women in the democratization process and finally the conclusion.

\section{THE LAWS, INTERNATIONAL COMMUNITY AND THE PARTICIPATION OF WOMEN IN DEMOCRATIZATION PROCESS}


Although West African governments have established laws and policies which encourage women's democratic participation; yet women are grappling with the challenges of participating within the political spaces, because men are still at the forefront of decisionmaking. For instance, in Nigeria government has the responsibility to ensure that all citizens are equally participating in transforming the country to a 30/70 parity so that everyone can enjoy the democratic privileges. Consequent upon this perspective, therefore, the People's Democratic Party (PDP) then, created a quota system so that there would be equal representation of men and women in governance. Quota system representation for women entails that women must constitute a certain number or percentage of the members of candidature in the National Assembly, a committee or government appointments (Dahlerup, 2005).

\section{OVERVIEW OF WOMEN POLITICAL PARTICIPATION IN THE DEMOCRATIZATION PROCESS OF SUB-SAHARAN AFRICA}

It was expected that the wave of democratization processes in the countries of Sub-Saharan Africa would open more opportunities for an increased women's political participation to fight for their interests. Now, many West African countries have a multiparty democracy with varying degrees of stability, acceptance, and legitimacy. The culture of political authoritarianism manifested in military dictatorship and one-party systems dominant in many African countries has in the last three decades gradually given way to democratic systems and numerous countries have embarked on constitutional reviews to promote the ethos of devotion to rule of law, due process and political accountability (Abdennebi-Abderrahim, n.d). The shift from one political party to multiparty, and in some cases from military to civilian rule, created favorable conditions for greater participation of women in public life, and even to aspire to positions of national leadership. Even if access to political space has been gradually less limited for African women, challenges in terms of political governance remain in many countries. The democratic process is often fragile, uneven and remains weak. The representation of women in government has been less impressive in the Sub-Saharan African countries. This made the former Liberian President Allen Sirleaf Johnson insisted on promoting women participation in politics. Virtually, most of the national constitutions in Africa recognized human rights and prohibit discrimination against gender, ethnic, religious, racial or geographical diversity (Abdennebi-Abderrahim, n.d). However, poverty, low literacy, the gap between urban and rural areas and other factors like customs, culture and the patriarchal gender system, are obstructing the full exercise of citizenship and political integration of the women.

It is noteworthy that the positive shift in attitude toward democratic transformation had a good impact on women's rights restructurings in Sub-Saharan Africa. Numerous women's association came to the fore in the 1990s and became instrumental in the swift overcoming of some of the women's constitutional and legal challenges. In fact, non-governmental organization's activisms have strongly helped to popularize and legitimize gender issues and put them on the agendas of political leaders, parliamentarians and human rights activists. The democratization process allowed women's organizations greater room to exercise their 
political rights in their various countries. These organizations have had a vital role in creating awareness. Indeed, in many countries, conservatives and religious leaders have influenced public discourse on gender issues and affected the adoption and implementation of women's human rights. Customary conservative beliefs that advocate men should lead while women follow restrains women's political participation (Susan \& Donley, 1996). Conservative women's groups are created to oppose measures to promote women's rights within the family and the community, using messages that exaggerate the class and cultural differences between women. In Mali a crowd estimated to be of about fifty thousand Malian men and women demonstrated against a new family code claiming it is against religion and culture (Susan \& Donley, 1996). It is instructive to note that despite the movement of conservativism in some parts of the Sub-Saharan African nations, Inter-Parliamentary Union has recorded that Rwanda is at the top of the 2018 record of female representation in global parliament, with nearly $2 / 3$ of its seats presently held by women (Thorston, 2019). Interestingly, the democratic space has now started to expand for women in the region which recorded an increase of about $20 \%$ in the cabinet. Indeed, the table below has indicated the regional average percentage of women representatives in the parliament across the globe which shows Sub-Saharan Africa to have about $23.6 \%$ in both the two chambers of the national assemblies.

Table 1

The Global Regional Average Percentage of Women Parliamentarians

\begin{tabular}{|c|c|c|c|}
\hline \multicolumn{4}{|c|}{ ISEGIONAL A Y $3 i S A G E S$} \\
\hline & $\begin{array}{l}\text { Single House } \\
\text { or lower House }\end{array}$ & $\begin{array}{l}\text { Upper House } \\
\text { or Senate }\end{array}$ & $\begin{array}{l}\text { Both Houses } \\
\text { combined }\end{array}$ \\
\hline Nordic countries & $42.3 \%$ & $\cdots$ & $\ldots$ \\
\hline Americas & $30.3 \%$ & $31.0 \%$ & $30.4 \%$ \\
\hline $\begin{array}{l}\text { Europe - OSCE member countries } \\
\text { including Nordic countries }\end{array}$ & $27.9 \%$ & $27.2 \%$ & $27.7 \%$ \\
\hline $\begin{array}{l}\text { Europe - OSCE member countries } \\
\text { excluding Nordic countries }\end{array}$ & $26.5 \%$ & $27.2 \%$ & $26.6 \%$ \\
\hline Sub-Saharan Africa & $23.8 \%$ & $22.3 \%$ & $23.6 \%$ \\
\hline Asia & $19.7 \%$ & $17.7 \%$ & $19.5 \%$ \\
\hline Arab States & $18.7 \%$ & $12.6 \%$ & $17.8 \%$ \\
\hline Pacific & $15.5 \%$ & $37.1 \%$ & $17.9 \%$ \\
\hline
\end{tabular}

Regions are classified by descending order of the pencentage of women in the lower or single House

Source: World Economic Forum Report, 2019

Furthermore, the following table shows the specific report on the Sub-Saharan African gender gap global index report. It indicates the regional slight improvement score of the top ten African nations out of the 142 countries studied in 2014. 
Table 2

The Sub-Saharan African Gender Gap Percentage Global Index Report

Sub-Saharan Africa Top 10
The Global Gender Gap Index
Rwanda

Source: World Economic Forum Report, 2014

Even though at the global level it is only $22 \%$ of national women parliamentarians or representatives as at 2018, it is worth noting that the Sub-Saharan African countries are generally making progress in giving women equal opportunities in the process of democratization and development. Indeed, over the years, Sub-Saharan African women have moved from the back seat to the roles of bread-winners, decision-makers and leaders of their immediate families. Irrespective of these progressive developments, women's contributions to national development still have slight impact on decisions that affect society, due to the marginalization which still holds strong in most developing countries (Ololade, 2018). Cultural and social norms, glass ceiling effects, and other exclusionary factors continue to dictate relegation of the presence and voice of women to a lower rank in public life. But regional and international organization, in partnership, have been on top of such issues and thus making commendable progress. For instance, the progress made by the AU, the New Partnership for Africa's Development (NEPAD) and the Economic Community of West African States (ECOWAS) with the translation of gender commitments into effective regional policies. They all support the current AU mechanisms for fostering gender equality and women's political participation and representation in decision-making. Not only that they address the AU's work in tandem with NEPAD, ECOWAS and civil society. They succeeded in identifying specific challenges and made some policy recommendations on advancing the elimination of gender gaps and promoting gender equality and the political empowerment of women throughout Africa (Institute for Democracy and Electoral Assistance IDEA, 2017). Women 
political involvement encourages gender equality by challenging the prevailing social and political structures which preserve the culture of women's subservience in both the private and public fields. Unarguably, including women in the democratic political processes would produce political and economic benefits. Politically, it increases the number of women in the parliament; it curbs corruption; it improves policies outcomes; and promotes the inclusiveness of minority groups in public spheres. Economically, it considers women as actors of development; it encourages the integration of women in the labor market, and it promotes economic and development growth.

\section{THE SOCIO-ECONOMIC AND RELIGIOUS CHALLENGES FACING WEST AFRICAN WOMEN POLITICAL PARTICIPATION IN THE DEMOCRATIZATION PROCESS}

Despite the tendency to treat women as a single and unified group, they hardly constitute a monolithic group with similar tribulations. Women live in nation state with varied historical experience and development levels, and within each nation the problems pertaining to women differ according to race, ethnicity, class, religion, tribe, residence, and educational levels (Anunobi, 2002). Despite these variations, the common denominator of women in all societies, including the developed ones, is their inferior status. Women constitute the poorest and the least powerful part of the population throughout the globe. The poor condition of women is strictly attributed to the socio-cultural and religious dogmas and values-which regularly define the formal, legal and institutional backgrounds-reportedly constitute the foremost impediment to women's political participation. (Anunobi, 2002). It has been previously stated that women have been politically excluded, and that, this has been done on purpose because of the perception that women are supposed to stay at home and not to be in the spaces of power (Hashim, 2004). Male domination and patriarchy are the reasons that women have had challenges in politics. Male domination occurs when men have power which is unchallenged or when they have power over women through how institutions are set (Young, 1997). There are three reasons as to why male domination exists. The first one is the creation of patriarchy. Patriarchy has given men the power to dictate how a woman should be and what her role is in society. Patriarchy is characterized by male domination and power in all activities of life (Hooks, 2004). The second reason is the exclusion of women from democratic institutions. Institutions are supposed to be gender indifferent, but they have also contributed to the oppression of women because they have created a platform in which men have power and women are excluded. Indeed, women's emancipation is a universal struggle but there is still a need to transform institutions because they are also part of the oppression of women (Eboh, 2004). The third reason is that there is an economic imbalance between men and women. Indeed, women's limited access to financial resources obstructs their participation in the democratization process especially in Sub-Saharan Africa (Eugene \& Joseph, 2019). The economic divide between men and women has led men to be economically independent and that has made women be economically dependent on men, but that does not mean that there are no few women who are economically independent. Thus, the economic 
division is one of the factors that are making men powerful. Thus, the economic sector has treated Sub-Saharan African women unfairly.

The introduction of quotas may be the solution for women's political participation as the political scene will be forced to bring in more women. Therefore, it would give them variety choices of candidates to elect (Shevedova, 2005). The quota system is not only a way of forcing men to include women into participating in politics, but it is also a way of strengthening the women cause. Hence, the quota system acts as a support system in which women can depend on, if their participation is being challenged. The last two decades have witnessed a wave of women entering politics at various levels of governing bodies. Most intellectuals have credited this surge to the implementation of gender quotas in several nations and Africa in particular (Tripp, 2006). Gender quotas are not a new phenomenon in Africa because Ghana was the first country to institute gender quotas in 1960. Moreover, Tripp further stated that four other nations that enacted gender quotas before 1995 were Tanzania (1975), Egypt (1976-1986), Senegal (1982), and Uganda (1989). The gender quotas necessitate that women must constitute a certain percentage of the members of a political organization, whether it is a candidate lists, a national assembly, or government appointment (Dahlerup, 2005). Supporters of gender quotas argue that gender quota is a means for the elimination of obstacles to women representation in politics started by the exclusionary practices of mostly political parties and political institutions. Most of the Sub-Saharan African countries have passed gender quotas laws to promote women entry into the political system thus reserved 30 to $50 \%$ of seats for women in the house of parliament, though Djibouti and Niger reserve only 10\% (Dahlerup, 2005). This figure presents the share and the number of Sub-Sahara African countries in the Social Institutions Gender Index (SIGI) classification. Thus, 39 of the 43 countries in the Sub-Sahara Africa are ranked in the SIGI by the level of discrimination of women.

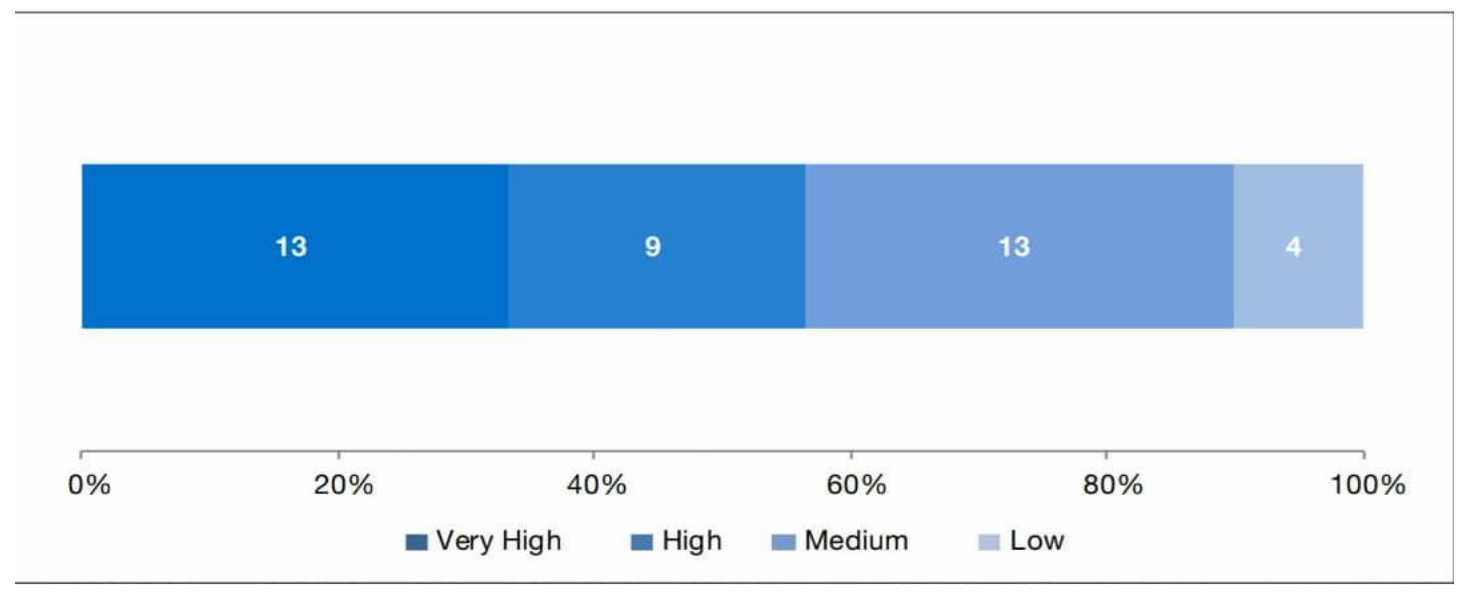

Figure 1: Share of sub-Saharan African countries by level of discrimination in the SIGI Source: OECD (2016), Gender, Institutions and Development Database, http://stats.oecd.org.

The table above shows that no country in the Sub-Saharan African region have been classified as having very low levels of gender-based discrimination in social institutions. These various number of obstacles bedeviling the African women led to the proliferation of 
women movements in the sub-region around the 1980s which aimed at complete socioeconomic and political transformations seen in economic liberalization and the democratization of politics to include all and sundry ((Emmanuelle, Rillon \& Cross, 2016).). This was reinforced by the United Nation's efforts on international women's movements which declared between 1975-185 as the international decade for women (Tripp, 2008). These efforts precipitated the emergence of women's associations in form of professional and advocacy groups who championed the cause of lobbying for women's right which fought for the reformation of the archaic customary practices and laws and harsh treatments of women among others ((Emmanuelle, Rillon \& Cross, 2016).). It has been asserted that the period between 1935 and 1950 was one in which the Sub-Saharan African women began to develop much interests in democratic politics of their countries for so many reasons ((Emmanuelle, Rillon \& Cross, 2016).). Two of such fundamental reasons were the emergence of militant Marxist oriented political groups which sought support from all the pressure and interest groups in the African societies and the increase in the number of educated women in Africa who were assisted by the professional and market women leaders to articulate their concerns. Importantly, this kind of women cooperative movements are still important even though some of the women's trepidations are gradually being surmounted. Unarguably, it has been attested that African women are, at present, experiencing a paradigm shift of inclusion in the democratization process by holding several positions in government

Undoubtedly, the increasing awareness of the women civic groups and the international women organizations have contributed to the development of democratization process in Sub-Saharan Africa. For instance, this has led to the formation of women political parties in some countries i.e. the Democratic Union of Cameroonian Women (DUCW). Meanwhile, with these developments societal institutions decayed by the male ruling political class, which led to the youth's frustration and violence, would easily be resurrected with the inclusion of women [as social mothers] in the democratic decision-making process (Sa'idu, Zakua \& Yusof, 2019).

\section{THE WAY FORWARD}

It is therefore suggested that civil society organizations as the bridge builders in between the state and the public should put extra efforts to empower women with skills and the needed information. That would give Sub-Saharan African women the chances of sustaining themselves in the democratization processes of their various societies. Again, civil society as a key player in the democratization process needs to work harder to empower women to ensure that their participation yields outcomes as it determines how the women are positioned in society. The improvement of the lives of the Sub-Saharan African women improves the lives of their families, strengthen their communities and create more opportunities for economic growth and opportunities. Truly, political institutions that are open to the full participation of women produce more effective institutions and more representative governments. So, investing in women employment, health and education would lead to greater economic growth across a broad spectrum. 
Similarly, there is a greater need for constitutional review in some of the West Africans nations to insert clauses that would further strengthen the position of women in the art of governance without any discrimination or bias. This would allow for the consultation of women in the activities of political parties and decision-making processes. Women must contribute to consolidating multiparty democracy in African sub-Saharan region which among other things means working towards enabling society to transform, which would consequently end discrimination and subordination of women. Data from around the world shows that economic growth is higher and poverty rates lower in countries with more gender equality. Therefore, since some women are making efforts of achieving some feats in the West African sub-region there is need to come up with a developmental initiative to empower them socially, economically and politically. In sum, a specific step to promote gender equality which would advance the status of women and young girls to fast track democratization in Sub-Saharan Africa is greatly needed. Beyond this highly specific goals, gender has been recognized globally through agreements and legal instruments as a crosscutting constituent that is central to creating an enabling atmosphere for achieving sustainable development and consolidation of democratic institutions at the local, national, regional and global levels.

\section{CONCLUSION}

The essay examines the historical experiences of Sub-Saharan African women in the democratization process. Women had been at the forefront of governance since before and during the colonial days in West Africa. They have been involved in the movement against colonial rule and during the post-colonial days, they remain relevant in the fight against military dictatorial regimes in the region. It has been established that the United Nations efforts around the 1980s through the 1970s women's rights movements were formed in Africa in the form of professional and advocacy groups. This aided the active engagement of women in the democratization process of Sub-Saharan African region which is seen in particularly Rwanda as the country with the highest female representatives in the parliament. The arguments have explicitly described the historical and political interactions of SubSaharan African women especially about to the contribution they have made during the precolonial days. However, the paper did not establish the contributions of the contemporary African women to the development of the region despite their improved chances of more inclusion in the democratization process beginning from the 1980 s to date. On this note, investigation of the successes, failures and the current challenges of the Sub-Saharan African women in the democratization process would make available a rich and resourceful insight.

\section{REFERENCE}

Abdennebi-Abderrahim, S. (n.d). Study on Discrimination against Women in Law and in Practice in Political and Public Life, Including During Times of Political Transitions.

Anunobi, F. (2002). Women and Development in Africa: From Marginalization to Gender Inequality. African Social Science Review, 2(2), 23-34. 
Charlotte, Bunch (1990). Women's Rights as Human Rights: Toward a Re-Vision of Human Rights." Human. Rights Quarterly, 12, 486-498.

Coffe, H. \& Catherine B. (2011). Gender Gaps in Political Participation Across SubSaharan African Nations. Social Indicators Research, 102(2), 245-264.

Dahlerup, D. (2005). Increasing Women's Political Representation: New Trends in Gender Quotas. Women in Parliament: Beyond Numbers 141.

Dahlerup, D. (2013). Women, quotas and politics. Routledge.

Daniel. K. (2012). Factors Affecting Women Participation in Electoral Politics in Africa." International Journal of Psychology and Behavioral Sciences, 2(3), 57-63.

Deckham, M, Dolan, J \& Swers, M.L. (2007). Women and Politics: Paths to Power and Political Influence. Upper Saddle River: Pearson Education.

Eboh, B. O. (2004). Women's Empowerment as a Struggle for Justice in Democratic Processes. na.

Emmanuel, B., Rillon \& Cross, H. (2016). African Women's Struggles in a Gender Perspective. Review of African Political Economy, 43(149), 338-349.

Eugene, E. D. \& Joseph Y. A. (2019). Socio-demographic Predictors of PoliticalParticipation Among Women in Nigeria: Insight from Afrobarometer 2015 Data. Journal of International Women's Studies, 20(2), 91-105.

Fallon, K. M., Swiss, L. \& Viterna, J. (2012). Resolving the democracy paradox: Democratization and Women's Legislative Representation in Developing Nations, 1975 to 2009" American Sociological Review, 77(3), 380-408.

Glendon, M. A. (2004). The Rule of Law in the Universal Declaration of Human Rights." Nw. UJ Int'l Hum. Rts. (2), 1-34.

Goetz, A. M. (1998). Women in Politics \& Gender Equity in Policy: South Africa \& Uganda." Review of African Political Economy, 25(76), 241-262.

Hassim, S. (2004). Nationalism, Feminism and Autonomy: The ANC in Exile and the Question of Women. Journal of Southern African Studies, 30(3), 433-456.

Heemann, L. (2013). Living Customary Law in South Africa: A Space for Women to Overcome Exclusion”. In: International Institute for Democracy and Electoral Assistance (ed). Journeys from Exclusion to Inclusion: Marginalized Women's Successes in Overcoming Political Exclusion 160-188.Stockholm: International IDEA.

Hooks, B. (2004). The Will to Change: Men, Masculinity, and Love. Beyond Words/Atria Books.

International Institute for Democracy and Electoral Assistance (International IDEA), (2017). Regional Organizations, Gender Equality and the Political Empowerment of Women.

Inter-Parliament Union (IPU). (2017). Women in Parliaments. An article posted on InterParliament Union. Accessed April 5, 2019, http://www.ipu.org/wmn-e/world.htm.

Jessica. C. (2014). Top 10 Most Gender Equal Countries in Sub-Saharan Africa. World Economic Forum Report. Accessed: May 4, 2019, https://www.weforum.org/agenda/2014/10/top-10- gender-equal-countries-subsaharan-africa/.

Mukasa, S. (2006). Domesticating the Protocol. In: Musa, R, Mohammed, F.J and Manji, F. (eds). Breathing Life into the African Union Protocol on Women's Rights in 
Africa. Nairobi: Solidarity for African Women's Rights and African Union Women, Gender and Development Directorate.

National Democratic Institute (NDI). (2019). Gender, Women, and Democracy: Overview. Accessed May 14, 2019, https://www.ndi.org/what-we-do/genderwomen-and- democracy.

Ololade, S. R. et al. (2018). Transcending Ethnic and Religious Barriers in DecisionMaking: A Case of a Muslim Women Civil Organization in Nigeria. Frontiers in Psychology(9), 1-44.

Olusegun, T. O. (2015). Women and Nigerian Politics: An Appraisal of 2015 General Elections. Accessed August 12, 2018, www.inecnigeria.org/wpcontent/uploads/2015/07/Conference- Paper-.

Organization for Economic Co-operation and Development (OECD). (2019). Sub-Saharan Africa, Social Institutions Gender Index Regional Report, accessed May 14, 2019 https://www.genderindex.org/wpGI_SSA_web.pdfontent/uploads/files/docs/Br ochure_SIGI_SSA_web.pdf.

Saidu, B. Zakua, U. A. B. A \& Yusof, K. H. (2019). The Nexus Between Youth Unemployment and Conflict in Southern Kaduna. Tamkang Journal of International Affairs, 22(4), 67-76. 10.6185/TJIA.V.201904_.

Sheila, R. (2013). Women in Movement (Routledge Revivals): Feminism and Social Action. London: Routledge.

Shimelis, K. (2014). Challenges and Opportunities of Women Political Participation in Ethiopia. Journal of Global Economics, 4(2), (2014), 22-45.

Shvedova, N. (2005). Obstacles to Women's Participation in Parliament. Women in Parliament: Beyond Numbers, 33, 22-45.

Sommer, R. \& Katherin S. (1990). Office Politics in State Legislature.” Environmental Behaviour, 20(5), 550-575.

Susan, W. \& Donley, T. S. (1996). The Opportunity Structure for Women's Candidacies and Electability in Britain and the United States. Political Research Quarterly, 49(94), 861-874.

Thornton, A. (2019). These Countries Have the Most Women in Parliament. World Economic Forum. Accessed May 3, 2019, https://www.weforum.org/agenda/2019/02/chart-of-theday- these- countries-have-the-most-women-in-parliament/.

Tripp A. M. (2019). Women and Politics in Africa. Oxford Research Encyclopedia of African History Ed. Thomas Spear. Oxford: Oxford University Press, accessed April 7, 2019, http://africanhistory.oxfordre.com/view/10.1093/acrefore/9780190277734.001.0001/a crefore9780190277734-e-192.

Tripp A. M. et al. (2008). African Women's Movements: Transforming Political Landscapes. New York: Cambridge University Press, 2008.

Tripp A. M., Dior K. \& Colleen L. M. (2006). Sub-Saharan Africa: On the Track to Women's Political Representation. 5(6), 36-48.

United Nations (UN). (2019). Political Participation. Accessed April 9, 2019 http://www.un.org/womenwatch/osagi/wps/publication/Chapter3.htm, (n.d.).

United Nations Agency for International Development (USAID). (2019). Strengthening women's rights and political participation. Accessed April 9, 2019 
https://www.usaid.gov/whatgender-equality-omensempowerment/addressing-genderprogramming/strengthening-womens.

Young M. I. (1997). Is Male Gender Identity the Cause of Male Domination? Na.

\section{Conflict of Interest Statement}

No conflict of interests has been declared by the authors 